\title{
EFFECTS OF LEAD STRESS ON THE CHLOROPHYLL CONTENT AND PHOTOSYNTHETIC FLUORESCENCE CHARACTERISTICS OF VALLISNERIA NATANS
}

\author{
GAO, G. Q. ${ }^{*}$ - ZENG, K. H. - JI, Y. - LI, W. - WANG, Y. \\ School of Civil and Architecture Engineering, Nanchang Institute of Technology \\ No. 289 Tianxiang Road, Nanchang, 330099 Jiangxi, China \\ (phone: +86-791-8209-6402; fax: +86-791-8812-6772) \\ *Corresponding author \\ e-mail: 342823307@qq.com; phone: +86-130-3723-2216 \\ (Received $9^{\text {th }}$ Dec 2018; accepted $4^{\text {th }}$ Mar 2019)
}

\begin{abstract}
In order to reveal the effects of lead stress on the chlorophyll content and fluorescence characteristics of Vallisneria natans, six $\mathrm{Pb}$ concentration levels were applied to a culture in clean river sand and water. The results showed that $\mathrm{Pb}$ could promote the synthesis of chlorophyll at a low concentration $\left(\mathrm{Pb} \leq 10 \mathrm{mg} \cdot \mathrm{L}^{-1}\right)$ in one day. $V$. natans had certain tolerance to the stress of low $\mathrm{Pb}$ concentration. With the prolongation of stress time and increasing $\mathrm{Pb}$ concentration, the leaves of $V$. natans gradually lost their green color. Chlorophyll a decreased more than chlorophyll $\mathrm{b}$. It had the least effect on carotenoids. Fv/Fm, Fv/Fo, qP, Y(II) and ETR decreased significantly $\left(\mathrm{Pb}>10 \mathrm{mg} \cdot \mathrm{L}^{-1}\right)$ in seven days. However, $q N, Y(N O)$ and $Y(N P Q)$ showed an upward trend. The efficiency of the leaves using light energy decreased noticeably, and the electron transport of PSII was blocked severely. It can be speculated that $V$. natans may be used in the phytoremediation of waters contaminated by a low concentration of lead.
\end{abstract}

Keywords: Vallisneria natans, lead stress, photosynthetic pigment, fluorescence characteristics, rapid light curve

\section{Introduction}

In recent years, heavy metal pollution has become prominent with mining, smelting, electroplating, and different types of wastewater, with solid wastes being discharged into water bodies (Ji et al., 2018). Due to the fact that these cannot degrade or be decomposed, heavy metals are accumulated in living organisms, impair the health of animals and humans with biological amplification through the food chain ( $\mathrm{Xu}$ et al., 2003). As one of the "five poisonous" heavy metal elements, lead $(\mathrm{Pb})$ is a non-essential element utilized during plant growth and metabolism, and otherwise has toxic effects (Sharma and Dubey, 2005; Bisht et al., 2013; Ansari et al., 2017; Shahid et al., 2016), inhibiting the progress of photosynthesis and reducing the activity of chlorophyllase.

Submerged macrophyte, as important primary producers in aquatic ecosystems, not only provide food, habitat and breeding sites for aquatic animals, but also can get rid of N, P and other nutrients (Song et al., 2011). It also has ability to adsorb and accumulate heavy metals (Pan et al., 2011; Chen et al., 2017), used to remove Pb from water (Li et al., 2011). The nutrient absorption, secondary metabolism and antioxidant response of Vallisneria natans (V. natans) under Pb stress were studied (Wang et al., 2011, 2012) Under $\mathrm{Pb}$ stress, malondialdehyde content increased and total chlorophyll and carotenoids decreased. $V$. natans had a certain resistance to $\mathrm{Pb}$ stress, and the key enzymes of nitrogen and phosphorus metabolism were more sensitive to the response of $\mathrm{Pb}$ stress ( $\mathrm{Yu}$ et al., 2016). At present, the research focus on mainly the enrichment of 
heavy metals (Liang et al., 2016; Xue et al., 2010), physiological and biochemical effects (Yu et al., 2016; Xu et al., 2006; Min et al., 2012), ultrastructure (Xu et al., 2004; Shi et al., 2000), etc. While the mechanisms of submerged macrophyte enduring heavy metals from photosynthetic and chlorophyll fluorescence are rarely reported.

$V$. natans is a perennial herbaceous plant perennial in China with high economic value (Wang et al., 2006), strong regeneration ability, used in water ecological restoration project widely (Gu et al., 2017; Wang et al., 2009). In 1980, professor Schreiber invented the pulse amplitude modulated. Due to the rapid, simple, sensitive, reliable and non-interference characteristics of the modulated fluorescence technology, it can reflect the "intrinsic" characteristics of the photosynthetic system (Hu et al., 2017), regarded as the effective probe in studying the relationship between plant photosynthesis and the degree of environmental stress (Janssen et al., 1992). The aims of this study were to investigate the intrinsic mechanism of photosynthetic system response under $\mathrm{Pb}$ stress, and provide some basic data and theoretical basis for the ecological restoration of $\mathrm{Pb}$ contaminated waters.

\section{Materials and methods}

\section{Materials cultivation and treatment}

Whole plants of $V$. natans were collecting from Nanjishan nature reserve of Poyang Lake, China, on June 5th in 2017. Plants (20 cm length) were planted in plastic buckets, adding 1/10 Hoagland nutrient solution, and acclimated for two weeks. Then, V. natans, healthy and consistent growth, were transplanted into eighteen transparent glass jars $(50 \mathrm{~cm} \times 40 \mathrm{~cm} \times 40 \mathrm{~cm})$ with $10 \mathrm{~cm}$ thick river sand paved at the bottom (Fig. 1). $50 \mathrm{~L}$ distilled water and $\mathrm{Pb}$ solution with different concentration levels were injected into the jars. $\mathrm{Pb}$ was added in the form of $\mathrm{Pb}\left(\mathrm{NO}_{3}\right)_{2}$ with a concentration level of $0,1,10,20$, 50 and $80 \mathrm{mg} \cdot \mathrm{L}^{-1}, 0 \mathrm{mg} \cdot \mathrm{L}^{-1}$ was the control group $(\mathrm{CK})$, three repetitions for each level.

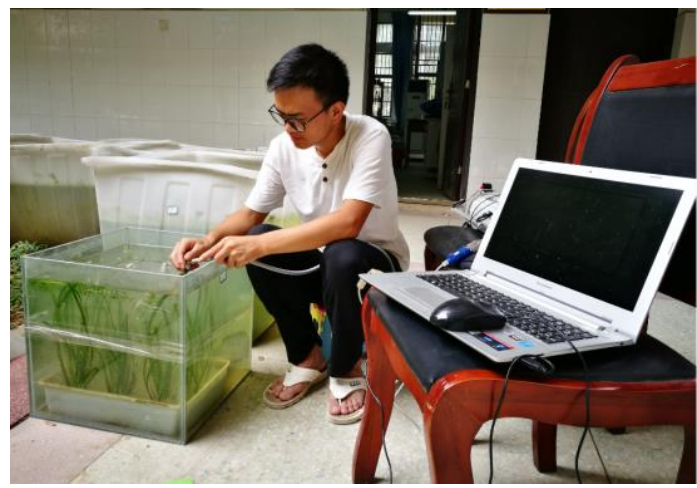

Figure 1. Diagram of experimental device

\section{Determination of chlorophyll content}

The determination of photosynthetic pigment was used by $95 \%$ ethanol extraction $(\mathrm{Li}, 2000)$. The value of absorbance was measured at 665,649 and $470 \mathrm{~nm}$, respectively. The concentrations of chlorophyll a $(\mathrm{Ca})$, chlorophyll $\mathrm{b}(\mathrm{Cb})$, carotenoid (Cc) and total chlorophyll $(\mathrm{Ct})$ in the extract were calculated respectively by Equations 1-4. The content of $\mathrm{Ca}, \mathrm{Cb}, \mathrm{Cc}$ and $\mathrm{Ct}\left(\mathrm{mg} \cdot \mathrm{g}^{-1}\right)$ was calculated by Equation 5. 


$$
\begin{gathered}
C_{a}\left(m g \bullet L^{-1}\right)=13.95 A_{665}-6.88 A_{649} \\
C_{b}\left(m g \bullet L^{-1}\right)=24.96 A_{649}-7.32 A_{665} \\
C_{c}\left(m g \bullet L^{-1}\right)=\frac{1000 A_{470}-2.05 C_{a}-114.8 C_{b}}{245} \\
C_{t}\left(m g \bullet L^{-1}\right)=C_{a}+C_{b} \\
\text { Chlorophyl content }\left(m g \bullet g^{-1} F W\right)=\frac{C_{t}\left(m g \bullet L^{-1}\right) \times \text { total amountof extract }(m l)}{\text { sample freshweight }(g)}
\end{gathered}
$$

\section{Determination of fluorescence parameters}

The chlorophyll fluorescence characteristics of $V$. natans leaves were determined by the underwater modulation fluorescence instrument (DIVING-PAM), produced by WALZ company in German. Before the measurement, the dark clips were clamped on the leaves of $V$. natans in situ. After dark adaptation for $20 \mathrm{~min}$, the clips and detection light were opened. First, the induction curve was determined, the minimum fluorescence (Fo) and maximum fluorescence (Fm) were obtained. The biggest actinic light efficiency of PSII (Fv/Fm), effective quantum yield (Y(II)), photochemical quenching coefficient $(\mathrm{qP})$, non-photochemical quenching coefficient $(\mathrm{qN})$ and quantum yield of regulatory energy dissipation (Y(NPQ)) and quantum yield of non-regulatory energy dissipation ( $\mathrm{Y}(\mathrm{NO})$ ) were calculated automatically by the selected system mode. $\mathrm{Fv} / \mathrm{Fo}=(\mathrm{Fm}-\mathrm{Fo}) /$ Fo. Then, the rapid light curve was measured. The gradients of photosynthetic active radiation (PAR) were 0, 100, 200, 300, 400, 600, 800, 1000 and $1200 \mu \mathrm{mol} \cdot \mathrm{m}^{-2} \cdot \mathrm{s}^{-1}$ respectively.

\section{Statistical analysis}

Excel 2017 was used to process the experimental data and draw graphics. SPSS19.0 was used for one-way analysis of variance. The Duncan method was used for multiple comparisons. $\mathrm{P}<0.05$ means significant difference.

\section{Results}

\section{Effects on photosynthetic pigment under Pb stress}

As shown in Figure $2 \mathrm{~A}, \mathrm{Ct}, \mathrm{Ca}$ and $\mathrm{Cb}$ after one day under $\mathrm{Pb}$ stress of $1 \mathrm{mg} \cdot \mathrm{L}^{-1}$ were increased significantly compared with the control group $(\mathrm{CK})$. The increase of $\mathrm{Ct}, \mathrm{Ca}$ and $\mathrm{Cb}$ under $\mathrm{Pb}$ stress of $10 \mathrm{mg} \cdot \mathrm{L}^{-1}$ was not significant compared with the $\mathrm{CK}$ $(\mathrm{P}>0.05) . \mathrm{Ct}, \mathrm{Ca}, \mathrm{Cb}, \mathrm{Cc}$ and $\mathrm{Ca} / \mathrm{Cb}$ were reduced significantly when $\mathrm{Pb}$ was over $20 \mathrm{mg} \cdot \mathrm{L}^{-1}$.

As shown in Figure $2 \mathrm{~B}, \mathrm{Ct}, \mathrm{Ca}$ and $\mathrm{Cb}$ were lower slightly after seven days under $1 \mathrm{mg} \cdot \mathrm{L}^{-1} \mathrm{~Pb}$. Above $10 \mathrm{mg} \cdot \mathrm{L}^{-1} \mathrm{~Pb}$ stress, $\mathrm{Ct}, \mathrm{Ca}, \mathrm{Cb}$ and $\mathrm{Cc}$ decreased significantly ( $\mathrm{P}<0.05)$. It was respectively $45.89 \%, 39.20 \%, 58.01 \%$ of the $\mathrm{CK}$ under $\mathrm{Pb}$ stress of $80 \mathrm{mg} \cdot \mathrm{L}^{-1} \cdot \mathrm{Ca} / \mathrm{Cb}$ appeared in overall downward trend. Ca was more sensitive than $\mathrm{Cb}$ under $\mathrm{Pb}$ stress, and decreased sharply. The damage of $\mathrm{Pb}$ stress on chlorophyll was 
larger than carotenoids. The leaves of $V$. natans lost green color gradually with the increase of $\mathrm{Pb}$ concentration.
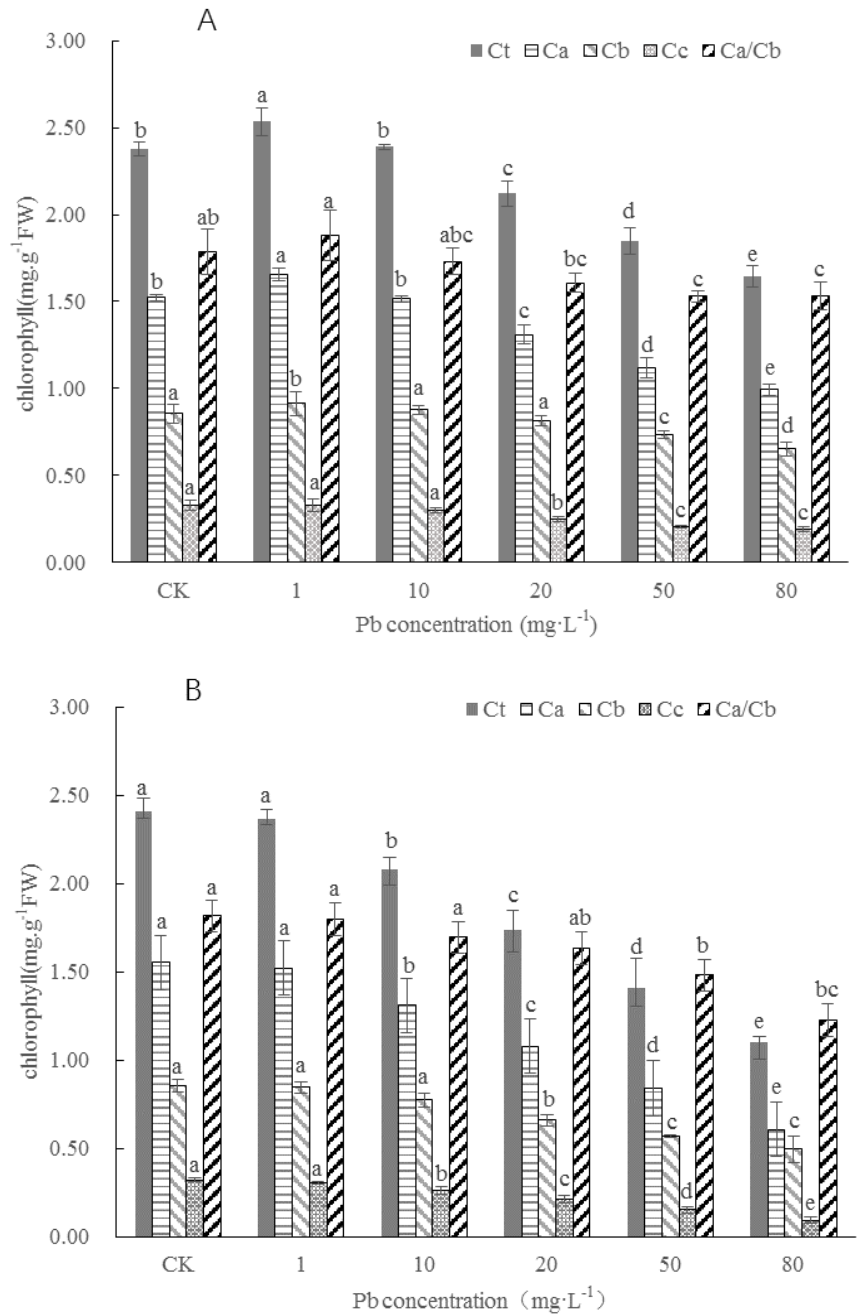

Figure 2. Varieties of $\mathrm{Ct}, \mathrm{Ca}, \mathrm{Cb}, \mathrm{Cc}$ and $\mathrm{Ca} / \mathrm{Cb}$ on $\mathrm{V}$. natans under Pb stress. (Different lowercase letters represent the significant differences $(P<0.05)$ in different treatment groups, the same below. A represents one day stress, $B$ represents seven days stress)

\section{Effect on Fo, Fm, Fv/Fm and Fv/Fo under Pb stress}

As shown in Figure 3, Fo decreased with the increase of $\mathrm{Pb}$ compared with the $\mathrm{CK}$ after one day, but the difference was not significant. Fm was less than the CK. Fm had little difference at $\mathrm{Pb}$ stress of $20-80 \mathrm{mg} \cdot \mathrm{L}^{-1}$. Fv/Fm was lower than that of the $\mathrm{CK}$ except at $\mathrm{Pb}$ stress of $1 \mathrm{mg} \cdot \mathrm{L}^{-1}$. $\mathrm{Fv} / \mathrm{Fm}$ had significant difference $(\mathrm{P}<0.05)$ under $\mathrm{Pb}$ stress of $10-80 \mathrm{mg} \cdot \mathrm{L}^{-1}$. The change trend of $\mathrm{Fv} / \mathrm{Fo}$ was similar with $\mathrm{Fv} / \mathrm{Fm}$.

After seven days, the increase of Fo was significant under the high $\mathrm{Pb}$ stress. Under $\mathrm{Pb}$ stress of $80 \mathrm{mg} \cdot \mathrm{L}^{-1}$, the increase of Fo was $28.32 \%$ compared with the CK. Fm was smaller than the $\mathrm{CK}$, also smaller than that of the same Pb stress after one day. Fm was $39.58 \%, 37.23 \%, 31.47 \%$ of the $\mathrm{CK}$ at $\mathrm{Pb}$ stress of $20-80 \mathrm{mg} \cdot \mathrm{L}^{-1}$. Fv/Fm was lower than the CK. Conversion efficiency of PS II primary light energy decreased with the increase of $\mathrm{Pb}$. Fv/Fo was also lower significantly than the $\mathrm{CK}(\mathrm{P}<0.05)$. 

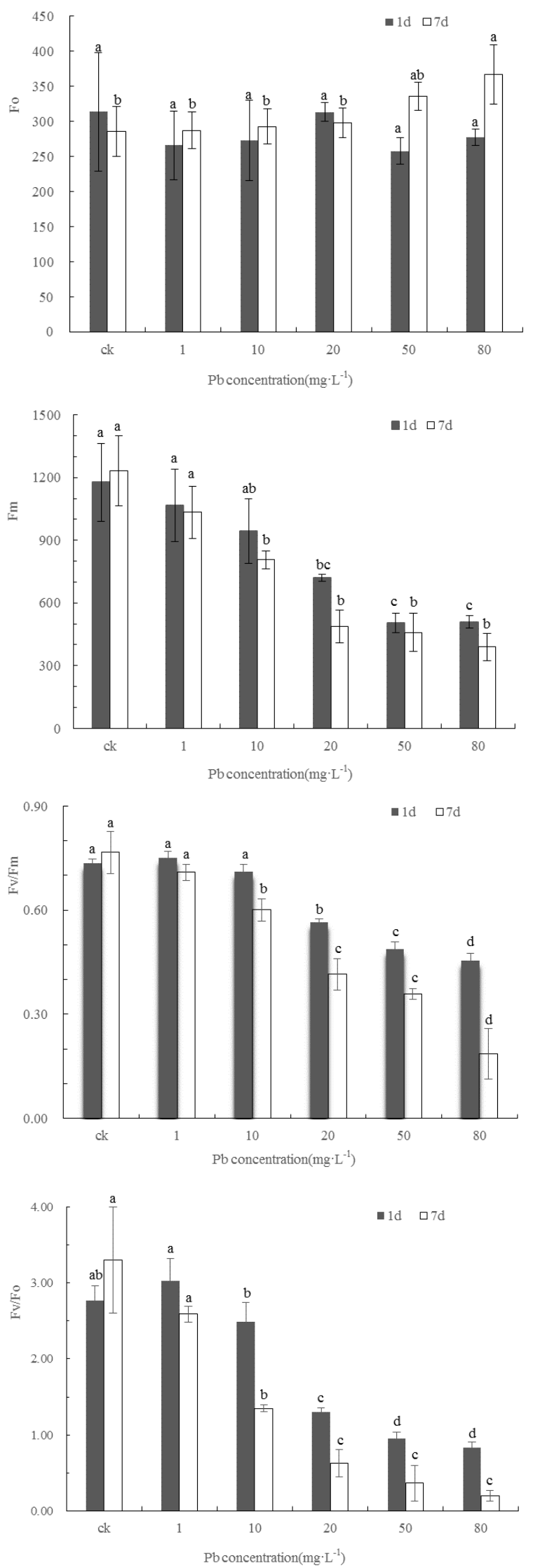

Figure 3. Effects on Fo, Fm, Fv/Fm and Fv/Fo of V. natans

APPLIED ECOLOGY AND ENVIRONMENTAL RESEARCH 17(2):4171-4181.

http://www.aloki.hu • ISSN 15891623 (Print) • ISSN 17850037 (Online)

DOI: http://dx.doi.org/10.15666/aeer/1702_41714181

(c) 2019, ALÖKI Kft., Budapest, Hungary 


\section{Effects on $q P, q N$ on leaves of $V$. natans under Pb stress}

The value of $\mathrm{qP}$ was in a downward trend with the increase of stress intensity (Fig. 4). It had no significant difference under $\mathrm{Pb}$ stress of $0-10 \mathrm{mg} \cdot \mathrm{L}^{-1}(\mathrm{P}>0.05)$ after one day. It decreased to $82.67 \%$ of the $\mathrm{CK}$ under $\mathrm{Pb}$ stress of $80 \mathrm{mg} \cdot \mathrm{L}^{-1}$ after one day, and $37.36 \%$ after seven days. The trend of $\mathrm{qN}$ was opposite to $\mathrm{qP}$. $\mathrm{qN}$ increased slowly with the increase of stress concentration. It peaked under $\mathrm{Pb}$ stress of $80 \mathrm{mg} \cdot \mathrm{L}^{-1}$, $141.3 \%$ higher than the CK.
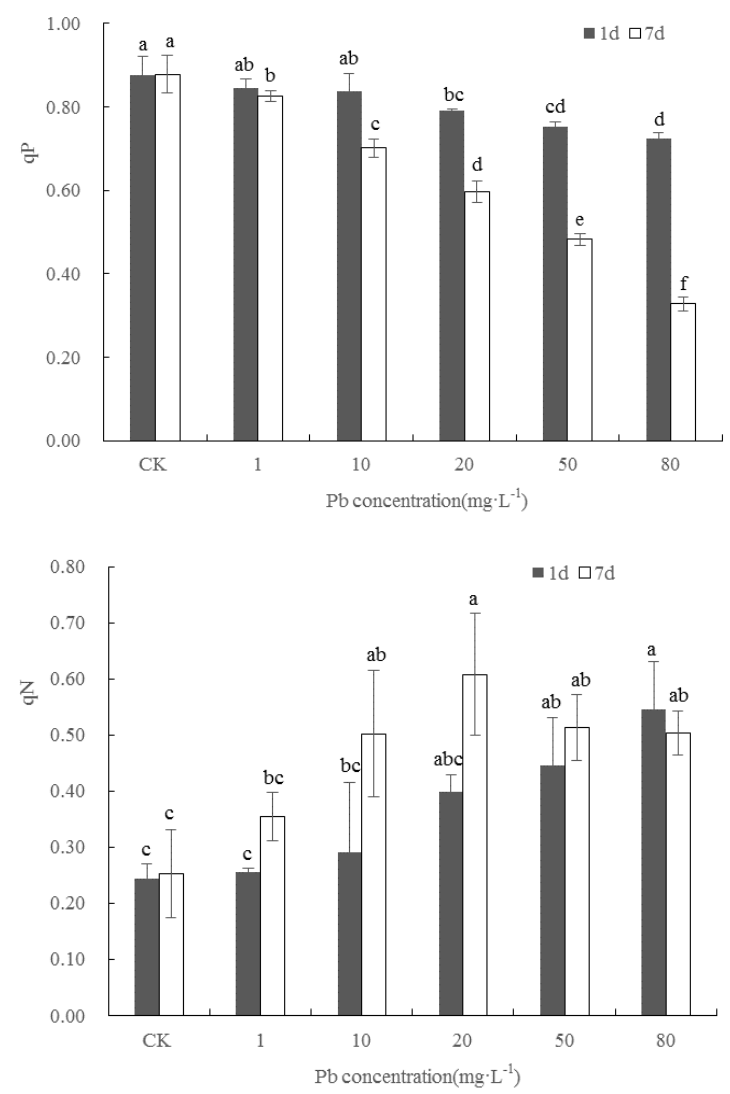

Figure 4. Effects on $q P$ and $q N$ on $V$. natans under Pb stress

\section{Effect on $\mathrm{Y}(\mathrm{II}), \mathrm{Y}(\mathrm{NO}), \mathrm{Y}(\mathrm{NPQ})$ under Pb stress}

$\mathrm{Y}(\mathrm{NO})$ increased slowly with the increase of stress concentration. The increase of $\mathrm{Y}(\mathrm{NO})$ was significant over $20 \mathrm{mg} \cdot \mathrm{L}^{-1} \mathrm{~Pb}$ after one day. Under the same stress concentration, $\mathrm{Y}(\mathrm{NO})$ after seven days was higher than that after one day, which was $1.01,1.01,1.05,1.08,1.14$ and 1.3 times respectively. Y(NPQ) showed an overall upward trend. Under $\mathrm{Pb}$ stress of $80 \mathrm{mg} \cdot \mathrm{L}^{-1}$, it peaked 4.05 times of the $\mathrm{CK}$, then decreased significantly $(\mathrm{P}<0.05)$ (Fig. 5).

\section{Response of rapid light curves under Pb stress}

The relative electron transfer rate (ETR) increased rapidly, then decreased and flattened. It behaved as light suppression. ETR increased compared with the CK under $\mathrm{Pb}$ stress of $1 \mathrm{mg} \cdot \mathrm{L}^{-1}$ and $10 \mathrm{mg} \cdot \mathrm{L}^{-1}$ after one day (Fig. 6A). It indicated low $\mathrm{Pb}$ could stimulate transmission of the electron. $V$. natans had certain resistance to low 
concentration. ETR was smaller than the CK under $\mathrm{Pb}$ stress of $20-80 \mathrm{mg} \cdot \mathrm{L}^{-1}$. The maximum of ETR appeared when PAR was $300 \mu \mathrm{mol} \cdot \mathrm{m}^{-2} \cdot \mathrm{s}^{-1}$. ETR was $91.42 \%$, $72.78 \%, 50.3 \%$ of the CK.

ETR in each treatment group was lower than the CK after seven days (Fig. 6B). ETR decreased significantly $(\mathrm{P}<0.05)$ with the prolongation of stress duration. The change trend was similar to that of $\mathrm{qP}$. The proportion of real electron transfer in light reaction center and absorbing light used in photochemical process reduced. Electron transfer in the leaves was significantly inhibited so photosynthetic efficiency weakened (Gan et al., 2017).
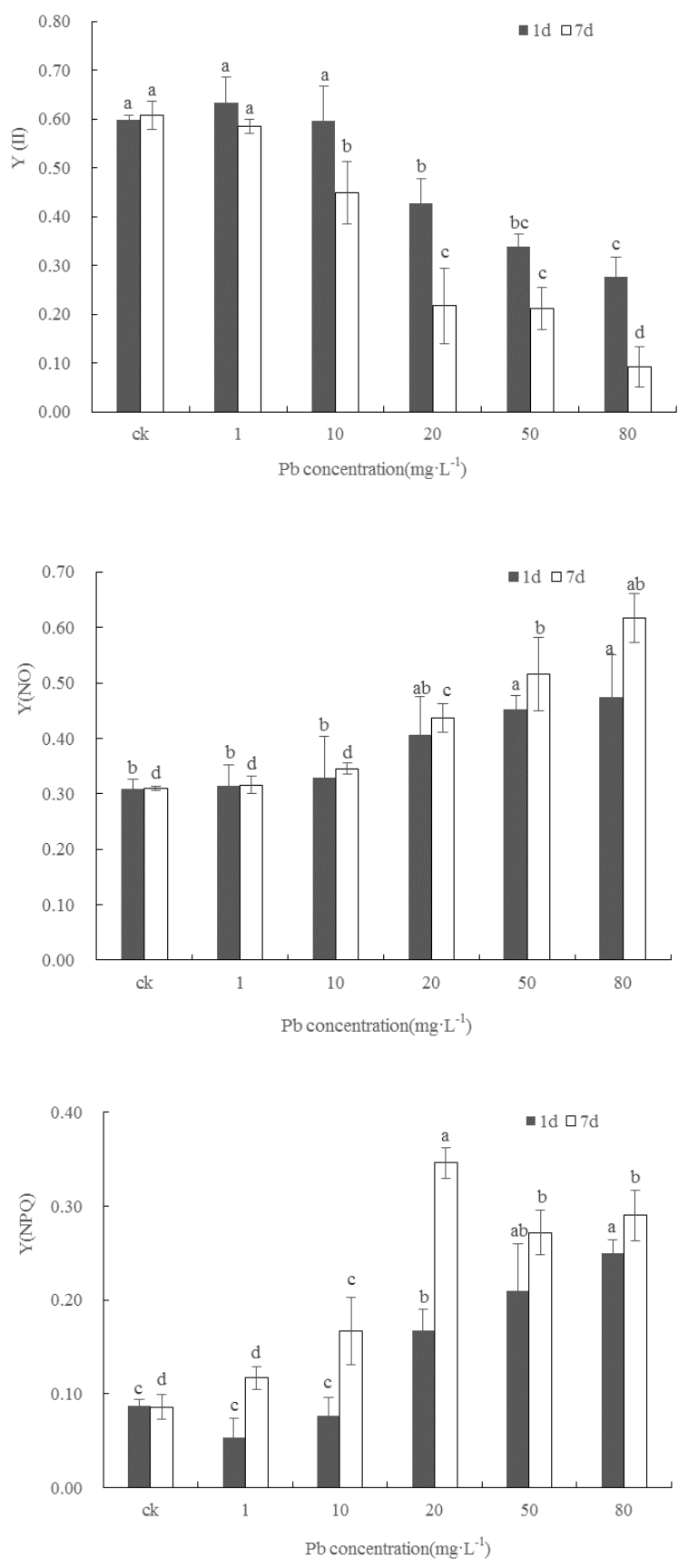

Figure 5. Effects on $Y(I I), Y(N O)$ and $Y(N P Q)$ of $V$. natans under Pb stress 

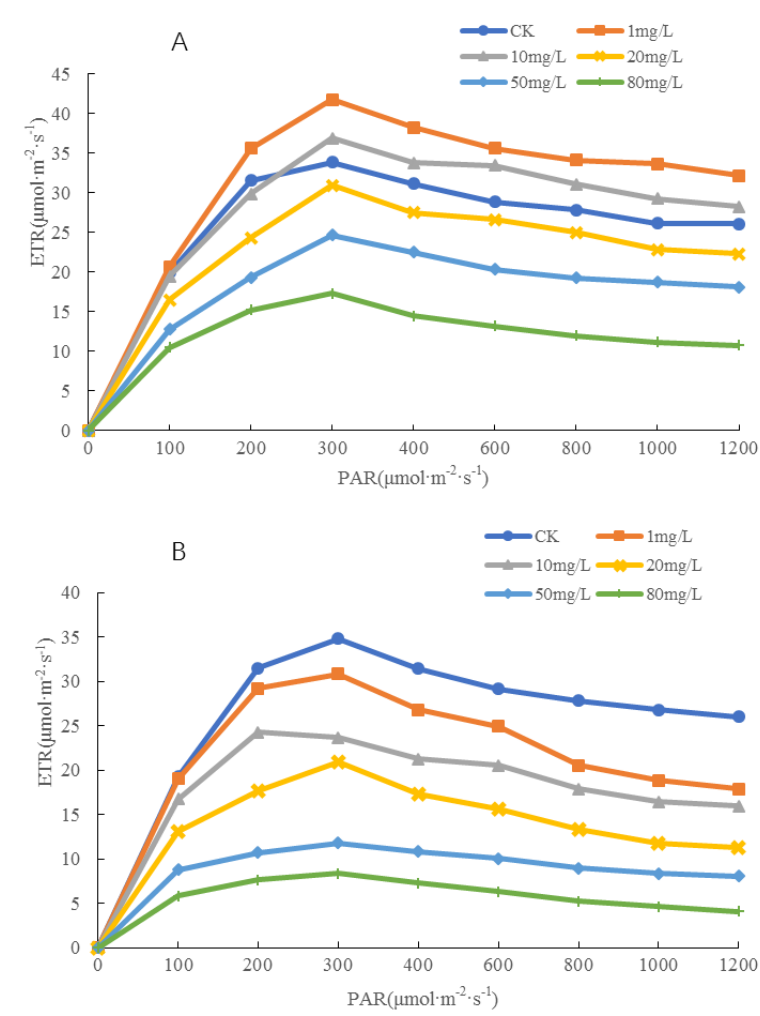

Figure 6. Effects on ETR of $V$. natans under Pb stress. (A represents one day stress, $B$ represents seven days stress)

\section{Discussion}

Chlorophyll content is an important index to measure leaf senescence. The degree of reduction can also reflect the situation of $\mathrm{Pb}$ poisoning in plants. After one day under $1 \mathrm{mg} \cdot \mathrm{L}^{-1} \mathrm{~Pb}$, the synthesis of chlorophyll was enhanced because activated microorganisms in the water improved the supply condition of water nutrients ( $\mathrm{Yu}$ et al., 2016), and $\mathrm{Ca} / \mathrm{Cb}$ increased which may be a kind of resistance caused by $\mathrm{Pb}$ accumulation in $V$. natans to slow down the aging speed of the leaves.

After seven days, $\mathrm{Ca}$ decreased faster than $\mathrm{Cb}$. Photosynthetic pigment decreased with the increase of $\mathrm{Pb}$ concentration. The main reason may be that $\mathrm{Pb}$ binds to the sulfhydryl of related enzyme in the chloroplast (Assche and Clijsters, 1990), destroyed the chloroplast structure. At the same time, with the accumulation of $\mathrm{Pb}$, the combination of $\mathrm{Pb}$ and some enzyme (original chlorophyll reductase and porphobilinogen deaminase) that synthesize chlorophyll in cells (Asgharipour., 2011), make the enzyme activity blocked and chlorophyll synthesis inhibited.

The parameters of chlorophyll fluorescence kinetic have been widely recognized as one of the good indicators of plant resistance. The fluorescence parameters of plant growing under normal conditions were stable (Roháček, 2002). Fo was related with the activity of PS II light reaction center. In this research, Fo increased obviously when $\mathrm{Pb}$ concentration was over $20 \mathrm{mg} \cdot \mathrm{L}^{-1}$, which may be caused by the damage of the PS II reaction center of $V$. natans leaves (Gan et al., 2017). Fv/Fm indicated the light conversion efficiency of PS II reaction center. Fv/Fo indicated the potential activity of PS II. The change trend of Fv/Fo change trend is similar with and Fv/Fm. Fv/Fo is more 
sensitive to change of the photosynthetic efficiency. Conversion efficiency of PS II primary light energy decreased with the increase of $\mathrm{Pb}$. The low $\mathrm{Pb}$ concentration had a weak effect on the potential maximum photosynthetic capacity of the leaves, and $V$. natans had a definite resistance to adversity. High $\mathrm{Pb}$ concentration hampered the light energy conversion efficiency of PS II reaction center, was unfavorable for the leaves to capture light energy into chemical energy.

After seven days, Fv/Fm, qP, Y(II) and ETR was 54.1\%, 67.99\%, 35.69\% and $67.99 \%$ of the CK respectively under $\mathrm{Pb}$ stress of $20 \mathrm{mg} \cdot \mathrm{L}^{-1}, 24.25 \%, 37.36 \%, 15.3 \%$ and $24.14 \%$ of the CK respectively under Pb stress of $80 \mathrm{mg} \cdot \mathrm{L}^{-1}$. This showed that with the prolongation of stress duration, the photosynthetic activity of PS II reaction center in $V$. natans leaves had been irreversibly damaged (Liu et al., 2017). It had basically lost photosynthetic capacity.

The decrease of $\mathrm{qP}$ indicated that the electron transportation from the oxidation side of PS II to the reaction center was blocked. The electrons used for photosynthesis decreased and the light energy dissipated in heat or other forms increased, which was consistent with the decrease of Y(II) (Zhang., 2016). qN reflects the plant's ability to dissipate excess light energy as heat and reflects the light protection ability of plants. The value of qN gradually increased with the increase of $\mathrm{Pb}$ level. V. natans would start self-protection mechanism, dissipate excess light energy absorbed by the antenna pigment as heat energy to reduce the damage of chloroplasts and other photosynthetic organs when it was threatened by the heavy metal (Qian et al., 2011; Wu et al., 2016; Janssen et al., 1992). With the prolongation of stress duration, the damage of leaves was severe under high $\mathrm{Pb}$ stress $\left(>20 \mathrm{mg} \cdot \mathrm{L}^{-1}\right)$. Dead leaves appeared. It was beyond the scope of self-protection.

Light quantum of adsorbed by PS II reaction center transferred and dissipated in three ways (Kramer et al., 2004). The sum of all light quantum yield closed to 1, that is, $\mathrm{Y}(\mathrm{II})+\mathrm{Y}(\mathrm{NO})+\mathrm{Y}(\mathrm{NPQ})=1$. The proportion of $\mathrm{Y}(\mathrm{II})$ was the smallest with the increase of $\mathrm{Pb}$ concentration. Excessive $\mathrm{Pb}$ directly inhibited the transportation of photosynthetic electron, thus reduce the percentage of energy conversion in photochemical way (Qian et al., 2011). Y(NO) is an important indicator of light damage. Its higher level indicates that the photochemical energy conversion and protective regulatory mechanisms (such as heat dissipation) are not sufficient to completely consume light energy absorbed by the plant. With the prolongation of stress time, it increased, indicating that $V$. natans had been damaged. Y(NPQ) is an important indicator of light protection. The higher of Y(NPQ) indicated that the light intensity accepted by the leaves was excess, the plant can adjust (such as the excess light energy dissipated into heat) in order to protect themselves. This research showed that Y(NPQ) after seven days was significantly higher than that after one day. It received excess light. The utilization of light energy by the plant was weakened under $\mathrm{Pb}$ stress. The plant consumed excessive heat to protect itself and adapt to the environment by increasing the quantum yield of regulatory energy dissipation ( $\mathrm{Li}$ et al., 2005).

\section{Conclusions}

Vallisneria natans can carry out relatively normal physiological activities $\left(\mathrm{Pb} \leq 10 \mathrm{mg} \cdot \mathrm{L}^{-1}\right)$. It can be speculated that $V$. natans are used as repairing species in low concentration $\mathrm{Pb}$ contaminated waters. This study was conducted in the period of vigorous growth, the period of flowering and decay of $V$. natans should be studied in future. 
Acknowledgements. This study was supported by Jiangxi Provincial Education Department (GJJ170978), National Natural Science Foundation of China (51369024, 51769016), Jiangxi Provincial Technology Department (20161BAB216109).

\section{REFERENCES}

[1] Ansari, Z., Singha, S. S., Saha, A. (2017): Hassle free synthesis of nanodimensional Ni, $\mathrm{Cu}$ and $\mathrm{Zn}$ sulfides for spectral sensing of $\mathrm{Hg}, \mathrm{Cd}$ and $\mathrm{Pb}$ : A comparative study. Spectrochimica Acta. Part A, Molecular and Biomolecular Spectrosopy 176: 67-78.

[2] Asgharipour, M. R., Khatamipour, M., Razavi-Omrani, M. (2011): Phytotoxicity of cadmium on seed germination, early growth, proline and carbohydrate content in two wheat verities. - Iranian Journal of Medical Physics 5(4): 559-565.

[3] Assche, F. V., Clijsters, H. (1990): Effects of metals on enzymes activity in plant. - Plant Cell and Environment 13(3): 195-206.

[4] Bisht, D., Yadav, S., Gautam, P., Darmwal, N. S. (2013): Simultaneous production of alkaline lipase and protease by antibiotic and heavy metal tolerant Pseudomonas aeruginosa. - Journal of Basic Microbiology 53(9): 715-722.

[5] Chen, G. L., Feng, T., Chen, Z. (2017): The influences of Cd, As, Pb enrichment by submerged plant on its Ca uptake. - Ecology and Environmental Sciences 26(5): 857-861.

[6] Gan, L., Luo, Y. H, Li, X. L., Xu, T., Dai, Z. L., Wang, L. Q., Huang, Y. P. (2017): Pb accumulation, growth and chlorophyll fluorescence of to different concentrations of $\mathrm{Pb}$ stress. - Journal of Agro-Environmental Science 36(5): 876-883.

[7] Gu, Y. F., Wang, J., Wang, J., Fan, G. S., Han, L. (2017): Morphological response and growth strategy of the submerged macrophyte Vallisneria natans under different water depths. - Journal of Lake Sciences 29(3): 654-661.

[8] Hu, F. J., Huang, X. H., Zhu, F., Zou, Z. G., Liu, J. W., Zheng, F. (2017): Application of chlorophyll fluorescence analysis in environmental stress. - Guangxi Forestry Science 46(1): 102-106.

[9] Janssen, L. H. J., Wams, H. E., Hasselt, P. R. V. (1992): Temperature dependence of chlorophyll fluorescence induction and photosynthesis in tomato as affected by temperature and light conditions during growth. - Journal of Plant Physiology 139(5): 549-554.

[10] Ji, Y., Wu, P. J., Zhang, J., Zhou, Y. F., Zhang, S. F., Cai, G. T., Gao, G. Q. (2018): Heavy metal accumulation, risk assessment and integrated biomarker responses of local vegetables: a case study along the Le'an river. - Chemosphere 199: 361-371.

[11] Li, H. S. (2000): Principles and Techniques of Plant Physiology and Biochemistry. Higher Education Press, Beijing.

[12] Li, P. M., Gao, H. Y., Reto, J. (2005): Application of the fast chlorophyll fluorescence induction dynamics analysis in photosynthesis study. - Journal of Plant Physiology and Molecular Biology 31(6): 559-566.

[13] Li, W. L., Zhang, G. S., Cheng, X. Y. (2016): Stress effect and response mechanism of $\mathrm{Cd}^{2+}, \mathrm{Cu}^{2+}, \mathrm{Zn}^{2+}$ and $\mathrm{Pb}^{2+}$ on Potamogeton crispus L. growth. - Journal of Food Science and Biotechnology 35(9): 1001-1007.

[14] Liang, S., Li, Z. Y., Yan, S. D., Zhao, J. F. (2016): Accumulation of lead in Elodea densa (Planch.) Casp. and its tolerance mechanism to lead. - Chinese Journal of Environmental Engineering 10(6): 3063-3070.

[15] Liu, T, Liu, W. Y., Liu, S., Song, L., Hu, T., Huang, J. B. (2017): Influence of $\mathrm{Pb}^{2+}, \mathrm{Zn}^{2+}$ stress on the chlorophyll content and photosynthetic fluorescence characteristics of epiphytic moss Homaliodendron montagneanum (C. Muell) Fleisch. - Chinese Journal of Ecology 36(7): 1885-1893.

[16] Min, H. L., Cai, S. J., Xu, Q. S., Shi, G. X. (2012): Effects of exogenous calcium on resistance of Hydrilla verticillata (L. f.) Royle to cadimum stress. - Acta Ecologica Sinica 32(1): 256-264. 
[17] Pan, Y. H., Wang, H. B., Gu, Z. P., Xiong, G. H., Yi, F. (2010): Accumulation and translocation of heavy metals by macrophytes. - Acta Ecologica Sinica 30(23): 64306441.

[18] Qian, Y. Q., Zhou, X. X., Hai, L., Sun, Z. Y., Ju, G. S. (2011): Rapid light-response curves of PS II chlorophyll fluorescence parameters in leaves of Salix leucopithecia subjected to cadmium-ion stress. - Acta Ecologica Sinica 31(20): 6134-6142.

[19] Roháček, K. (2002): Chlorophyll fluorescence parameters: the definitions, photosynthetic meaning, and mutual relationships. - Phtosynthetica 40(1): 13-29.

[20] Shahid, M., Dumat. C., Khalid, S., Schreck, E., Xiong, T. (2016): Foliar heavy metal uptake, toxicity and detoxification in plants: A comparison of foliar and root metal uptake. - Journal of Hazardous Material 325: 36-58.

[21] Sharma, P., Dubey, R. S. (2005): Lead toxicity in plants. - Brazilian Journal of Plant Physiology 17(1): 35-52.

[22] Song, Y. Z., Yang, M. J., Qin, B. Q. (2011): Physiological response of Vallisneria natans to nitrogen and phosphorus concents in eutropic waterbody. - Environmental Science 32(9): 2569-2575.

[23] Wang, C., Lu, J., Zhang, S., Wang, P. F., Hou, J., Qian, J. (2011): Effects of Pb stress on nutrient uptake and secondary metabolism in submerged macrophyte Vallisneria natans. - Ecotoxicology and Environmental Safety 74: 1297-1303.

[24] Wang, G. X., Zhang, L. M., Chua, H. (2009): A mosaic community of macrophytes for the ecological remediation of eutrophic shallow lakes. - Ecological Engineering 35(4): 582-590.

[25] Wang, P. F., Zhang, S. H., Wang, C., Lu, J. (2012): Effects of Pb on the oxidative stress and antioxidant response in a $\mathrm{Pb}$ bioaccumulator plant Vallisneria natans. Ecotoxicology and Environment Safety 78: 28-34.

[26] Wang, Y. L., Xiao, Y., Pan, H. Y., Fu, C. Z., Gao, S. X. (2006): Analysis of nutrient composition and comprehensive utilization of submersed aquatic macrophytes (Vallisneria natans). - Journal of Ecology and Rural Environment 22(4): 45-47.

[27] Wu, H., Gao, Y., E, M. (2016): Characteristics of chlorophyll fluorescence parameters in Forsythia suspensa (Thunb.). - Northern Horticulture 7: 55-60.

[28] Xin, G. X., Du, K. H., Xie, K. B., Ding, X. Y., Chang, F. C., Chen, G. X. (2000): Ultrastructural study of leaf cells damaged from $\mathrm{Hg}^{2+}$ and $\mathrm{Cd}^{2+}$ pollution in Hydrilla verticillata. - Acta Botanica Sinica 42(4): 373-378.

[29] Xu, Q. S., Shi, G. X., Zhou, H. W., Xu, N., Zhang, X. L., Zeng, X. M. (2003): Effects of $\mathrm{Cd}$ and $\mathrm{Zn}$ combined pollution on chlorophyll content and scavenging system of activated oxygen in leaves of Ottelia alismoides (L.) Pers. - Chinese Journal of Ecology 22(1): 5-8.

[30] Xu, Q. S., Shi, G. X., Zhou, Y. M., Wu, G. R., Wang, X. (2004): Distribution and toxicity of cadmium in Hydrilla verticillata (L. f.) Royle. - Acta Biologiae Experimentalis Sinica 37(6): 461-468.

[31] Xu, Q. S., Shi, G. X., Wang, X., Wu, G. R. (2006): Generation of active oxygen and change of antioxidant enzyme activity in Hydrilla verticillata under $\mathrm{Cd}, \mathrm{Cu}$ and $\mathrm{Zn}$ stress. - Acta Hydrobiologica Sinica 30(1): 107-112.

[32] Xue, P. Y., Li, G. X., Liu, W. J., Yan, W. J. (2010): Copper uptake and translocation in a submerged aquatic plant Hydrilla verticillata (L. f.) Royle. - Chemosphere 81(9): 1098103.

[33] Yu, S., Zhang, S. G., Cheng, X. Y. (2016): Impact of the Pb-stress on the physiobiochemical features associated with the key-metabolic enzymes of $\mathrm{N}$ and $\mathrm{P}$ in Vallisneria. - Journal of Safety and Environment 16(1): 372-376.

[34] Zhang, W. B., Xie, Y., Huang, R., Qian, W., Wang, J. (2016): Effects of water pollution of copper on the chlorophyll fluorescence parameters and the growth of Eichhornia crassipes. - Journal of Fujian Normal University (Natural Science Edition) 32(2): 55-61. 